\title{
FAKTOR-FAKTOR YANG MEMPENGARUHI KOMITMEN KARIER
}

\author{
Tri Muji Ingarianti \\ Program Doktor, Fakultas Psikologi Universitas Airlangga \\ tri_ingarianti@yahoo.com
}

\begin{abstract}
Komitmen karier adalah sikap yang ditunjukkan individu dalam mencapai tujuan karier. Penelitian ini bertujuan untuk mengkaji hasil-hasil penelitian (literature review) mengenai faktor-faktor yang mempengaruhi komitmen karier pada individu. Penelusuran literatur dilakukan pada database elektronik SAGE Journals, ProQuest, dan Science Direct dengan menggunakan kata kunci "career commitment". Hasil penelusuran menunjukkan bahwa komitmen karier dipengaruhi oleh faktor internal dan eksternal. Faktor internal yang mempengaruhi komitmen karier terdiri dari komitmen organisasi, keterlibatan kerja, kepuasan kerja, nilai kerja, pengalaman kerja, kepribadian, dan selfefficacy sedangkan faktor eksternal terdiri dari situasi kerja yang meliputi kondisi kerja, persepsi pensiun, persepsi terhadap ancaman dalam bekerja, dorongan yang ditawarkan organisasi (offered inducements), kontribusi yang diharapkan organisasi (expected contributions), peluang promosi, dan reward.
\end{abstract}

Kata kunci: Karier, komitmen karier

Career commitment is the attitude that individuals show in achieving career goals. This study aims to examine the results of research or literature review on the factors that affect career commitments in individuals. The literature search was conducted on SAGE Journals, ProQuest, and Science Direct electronic databases using the keyword "career commitment". Search results showed that career commitments are influenced by internal and external factors. Internal factors affecting career commitment consist of organizational commitment, job involvement, job satisfaction, work value, work experience, personality, and self-efficacy while external factors consist of work situations covering working conditions, retirement perception, perceptions of threats in work, encouragement offered by the organization (offered inducements), the expected contribution of the organization (expected contributions), promotion opportunities, and rewards.

Keywords: Career, career commitment 
Karier merupakan hal yang penting pada kehidupan seseorang. Proses perkembangan individu sangat berkaitan dengan perkembangan kariernya. Salah satu bentuk pemenuhan kebutuhan individu adalah pencapaian karier. Banyak individu yang menghabiskan waktu dan tenaganya dalam mencapai karier yang diinginkan. Pada era sekarang, organisasi tidak dapat menjamin apakah pekerja akan bertahan lama pada organisasi tersebut, beberapa pekerja cenderung termotivasi untuk berkomitmen dengan kariernya dibandingkan dengan organisasi tempatnya bekerja. Individu yang gigih dan mau mengeluarkan seluruh energinya dalam mencapai tujuan karier dapat dianggap sebagai individu yang memiliki komitmen karier yang tinggi. Individu tersebut biasanya cenderung rela untuk berpindah-pindah dari satu organisasi ke organisasi lain demi mencapai karier yang diinginkannya.

Komitmen karier memiliki konsep yang berbeda dengan komitmen organisasi. Seseorang bisa saja berkomitmen pada kariernya tetapi tidak berkomitmen pada organisasi dan begitu pula sebaliknya. Komitmen karier didefinisikan sebagai sikap seseorang terhadap pekerjaan atau profesinya (Blau, 1985) sedangkan komitmen organisasi adalah tingkat keterlibatan dan identifikasi seseorang terhadap organisasi (Hellriegel \& Slocum, 2011). Komitmen karier lebih berfokus pada pengembangan diri individu dibandingkan pada organisasi. Hal tersebut didukung oleh pernyataan Ching dan Kee (2012) bahwa komitmen karier mengukur seberapa jauh seseorang berharap mengalami perkembangan dan kemajuan pada kariernya dan keputusan ini tidak berhubungan dengan organisasi.

Komitmen karier merupakan hal yang penting dalam perkembangan karier seseorang. Penelitian yang dilakukan oleh Ballout (2009) ditemukan bahwa komitmen karier berdampak terhadap kesuksesan karier seseorang. Komitmen karier dapat memprediksi kesuksesan karier objektif (tingkat gaji) dan kesuksesan karier subjektif (kepuasan karier) pada individu dengan tingkat self-efficacy menengah hingga tinggi. Individu dengan komitmen karier dan self-efficacy yang tinggi cenderung memiliki tingkat gaji yang tinggi dan kepuasan karier yang tinggi pula. Hal tersebut juga didukung oleh penelitian yang dilakukan oleh Pasha, Hamid, dan Shahzad (2017) juga menunjukkan bahwa praktek pengembangan karier (misalnya peluang promosi) memiliki hubungan yang positif dengan komitmen karier dan kesuksesan karier. Alzyoud (2017) juga menemukan bahwa komitmen karier, career value, dan organizational support memiliki hubungan yang positif dan signifikan dengan kesuksesan karier. Berdasarkan pemaparan tersebut, diketahui bahwa penting untuk mengkaji faktor-faktor apa saja yang mempengaruhi komitmen karier pada individu.

Penelitian ini bertujuan untuk mengkaji hasil-hasil penelitian mengenai faktor-faktor yang mempengaruhi komitmen karier pada individu. Diharapkan melalui penelitian ini, dapat diketahui lebih mendalam mengenai komitmen karier dan berguna untuk penelitian selanjutnya.

Ching \& Kee (2012) menyatakan bahwa komitmen karier adalah sikap seseorang dalam mencapai tujuan demi kemajuan diri dan lebih bersifat individualis. Blau (1985) mendefinisikan komitmen karier sebagai sikap seseorang terhadap pekerjaan atau profesinya. Ia juga menambahkan bahwa komitmen karier menunjukkan sejauh mana seseorang mengidentifikasikan nilai-nilai dalam dirinya dengan profesinya (Blau, 1985). Hal yang sama juga dinyatakan oleh Goulet dan Singh (2002) di mana komitmen karier adalah suatu keadaan yang menunjukkan sejauh mana seseorang mengidentifikasi nilai 
profesi, pekerjaan, jumlah waktu, dan usaha yang diberikan untuk memperoleh pengetahuan yang relevan. Komitmen karier ditunjukkan individu melalui keinginan untuk berkorban dan bertahan dalam mencapai karier yang diinginkan.

Komitmen karier adalah faktor penting yang membantu individu untuk bertahan pada suatu pekerjaan tertentu dalam waktu yang cukup lama demi mengembangkan keterampilan khusus yang dimiliki individu tersebut (Niu, 2010). Hall (1971) menyebutkan bahwa komitmen karier melibatkan perasaan individu terhadap dirinya apakah ia berkompeten dan akan sukses dalam kariernya tersebut. Ia juga memandang komitmen karir sebagai kekuatan dari motivasi seseorang untuk bekerja pada peran karier yang dipilihnya (Hall, 1971). Motivasi tersebut mendorong seseorang dalam bekerja untuk menuju kemajuan pribadi dan mencapai tujuan karier (Ellemers, dkk., 1998). Melalui komitmen karier, individu akan terdorong untuk mengembangkan keterampilan yang dimiliki.

Collarelli \& Bishop (1990) menyatakan bahwa komitmen karier melibatkan pengembangan tujuan karier serta identifikasi dan keterlibatan individu dalam mencapai tujuan karier tersebut. Komitmen karier juga dapat mengukur seberapa jauh seseorang berharap mengalami perkembangan dan kemajuan pada kariernya dan tidak memiliki hubungan dengan organisasi (Ching \& Kee, 2012). Hal tersebut menunjukkan bahwa komitmen karier sangat memperhatikan peranan individu dalam mencapai tujuan kariernya.

\section{METODE}

\section{Strategi Penelusuran}

Penelitian ini termasuk pada penelitian systematic review dengan menggunakan metode kualitatif (meta-sintesis). Lalu, pendekatan yang digunakan dalam penelitian ini adalah meta-etnograf, yaitu peneliti merangkum berbagai hasil penelitian yang relevan secara naratif dengan tujuan mengembangkan teori baru untuk melengkapi teori yang sudah ada (Siswanto, 2010).

Pada tanggal 17 Juni 2017 dilakukan penelusuran hasil penelitian di database elektronik SAGE Journals (http://journals.sagepub.com/), ProQuest (https://search.proquest.com/), dan Science Direct (http://www.sciencedirect.com/). Database elektronik tersebut menyediakan berbagai artikel publikasi pada berbagai disiplin ilmu, seperti kesehatan, sosial, teknik, dan medis. Database elektronik tersebut dipilih karena mengindeks lebih banyak hasil-hasil penelitian di bidang sosial khususnya psikologi. Kurun waktu periode publikasi dibatasi mulai tahun 2002 hingga 2017.

\section{Kriteria Seleksi}

Dari hasil penelusuran yang telah dilakukan, peneliti membaca judul dan abstrak penelitian untuk mengetahui apakah artikel tersebut memenuhi kriteria untuk dikaji. Kriteria yang digunakan adalah: 1) artikel penelitian membahas tentang komitmen karier; 2) artikel membahas tentang pengaruh variabel $x$ terhadap komitmen karier; 3) artikel berisi laporan hasil penelitian (original article); 4) artikel ditulis dalam Bahasa Inggris. Peneliti memperoleh 20 artikel publikasi tetapi setelah proses seleksi, hanya 10 artikel 
publikasi yang relevan untuk dikaji. Sepuluh artikel publikasi yang lain tidak relevan karena tidak membahas mengenai pengaruh variabel x terhadap komitmen karier.

\section{Analisis}

Pada penelitian ini peneliti melakukan identifikasi, evaluasi, dan interpretasi terhadap semua hasil penelitian yang relevan terkait komitmen karier secara naratif. Tujuan penelitian ini adalah untuk mengidentifikasi faktor-faktor yang mempengaruhi komitmen karier. Peneliti mengumpulkan 10 artikel publikasi yang relevan untuk dikaji dan membuat rangkuman hasil-hasil penelitian yang mencakup nama peneliti, tahun publikasi, jumlah subjek, alat ukur yang digunakan, dan hasil penelitian. Dari hasil tersebut, peneliti menarik kesimpulan mengenai faktor-faktor yang mempengaruhi komitmen karier.

\section{HASIL}

Berdasarkan hasil analisis pada 10 artikel publikasi yang relevan untuk dikaji, diperoleh hasil sebagai berikut.

\section{Komitmen Organisasi}

Komitmen organisasi menjadi salah satu faktor yang dapat mempengaruhi komitmen karier pada individu. Hasil analisis data pada 228 karyawan di Timur Laut Amerika oleh Goulet dan Singh (2002) menemukan bahwa komitmen organisasi memberikan pengaruh yang signifikan terhadap komitmen karier. Hal tersebut didukung oleh penelitian yang dilakukan oleh Nazish, dkk. (2013) pada 197 karyawan bank di Pakistan di mana juga menemukan bahwa komitmen organisasi memberikan dampak langsung dan signifikan terhadap komitmen karier.

\section{Keterlibatan Kerja}

Keterlibatan individu dalam bekerja juga dapat mempengaruhi komitmen karier. Goulet dan Singh (2002) melakukan penelitian pada 228 karyawan di Timur Laut Amerika menemukan bahwa keterlibatan kerja memberikan pengaruh yang signifikan terhadap komitmen karier.

\section{Kepuasan Kerja}

Pengaruh dari kepuasan kerja terhadap komitmen karier ditemukan pada penelitian yang dilakukan oleh Goulet dan Singh (2002) di mana kepuasan kerja memberikan pengaruh yang signifikan terhadap komitmen karier. Hasil yang sama juga ditemukan oleh Nazish, dkk. (2013) yang menemukan bahwa kepuasan kerja memiliki dampak langsung dan signifikan terhadap komitmen karier. Sebaliknya, Animasahun dan Oludemi (2013) tidak menemukan adanya dampak yang signifikan dari kepuasan kerja terhadap komitmen karier.

\section{Nilai Kerja}

Penelitian mengenai komitmen karier dilakukan oleh Ching dan Kee (2012) pada 101 guru generasi Y di salah satu institusi pelatihan guru di Malaysia dan menemukan bahwa nilai kerja intrinsik secara signifikan berpengaruh terhadap komitmen karier. Para guru tersebut lebih memilih nilai kerja yang berhubungan dengan lingkungan dan keamanan. 


\section{Situasi Kerja}

Nazish, dkk. (2013) menemukan bahwa kondisi kerja saat ini berpengaruh terhadap komitmen karier. Kondisi kerja atau situasi kerja saat ini meliputi posisi jabatan, job security, tingkat manajemen, dan pemenuhan harapan. Selain itu, Smith, Conley, dan You (2015) melakukan penelitian pada 247 guru SD, SMP, dan SMA di California dan menemukan bahwa terdapat pengaruh dari persepsi pensiun terhadap komitmen karier. Adapun, penelitian yang dilakukan Ugboro dan Obeng (2015) pada 220 professor di universitas menemukan bahwa persepsi terhadap ancaman dalam bekerja secara negatif berdampak pada komitmen karier. Pada penelitian tersebut, evaluasi terhadap jabatan dipersepsikan sebagai ancaman kerja seperti job autonomy dan total job. Cai, dkk. (2017) menemukan bahwa terdapat dampak dari dorongan yang ditawarkan organisasi (offered inducements) dan kontribusi yang diharapkan organisasi (expected contributions) terhadap komitmen karier. Selain itu, penelitian yang dilakukan Pasha, Hamid, dan Shahzad (2017) pada 374 karyawan pada sektor asuransi di Pakistan menemukan bahwa peluang promosi dan reward memiliki pengaruh yang signifikan terhadap komitmen karier.

\section{Pengalaman Kerja}

Penelitian pada 197 karyawan bank di Pakistan yang dilakukan oleh Nazish, dkk. (2013) menemukan bahwa terdapat pengaruh dari pengalaman kerja terhadap pengalaman kerja. Pengalaman kerja tersebut meliputi tingkatan karier, pola mobilitas, kepuasan karier, dan perubahan industri. Hal tersebut bertolak belakang dengan hasil penelitian yang dilakukan oleh Animasahun dan Oludemi (2013) di mana ditemukan bahwa tidak ada dampak yang signifikan dari pengalaman kerja terhadap komitmen karier.

\section{Kepribadian}

Faktor kepribadian juga dapat mempengaruhi komitmen karier individu. Arora dan Rangnekar (2016) menemukan bahwa interaksi antara trait conscientiousness dan agreeableness memberikan dampak parsial (sebagian) pada komitmen karier karyawan. Maksud dari dampak parsial ini adalah interaksi antara variabel conscientiousness dan agreeableness bertindak sebagai prediktor yang signifikan pada resiliensi karier tetapi tidak bertindak sebagai predictor pada identitas karier dan perencanaan karier.

Selain itu, penelitian yang dilakukan oleh Xiao, dkk. (2014) pada 167 mahasiswa dari 3 universitas medis di Xi'an, Cina dan menemukan bahwa vocation fit (kesesuaian pekerjaan denga kepribadian) dan core self-evaluation dapat mempengaruhi komitmen karier pada mahasiswa medis ketika kepuasan kerja dan kondisi kecemasan berperan sebagai mediator.

\section{Self-efficacy}

Niu (2010) melakukan penelitian pada 1025 karyawan di industri pelayanan makanan di Taiwan dan menemukan bahwa tingkat komitmen karier juga berbeda karena dipengaruhi oleh tingkat self-efficacy yang tinggi. Semakin tinggi self-efficacy karyawan, maka semakin tinggi pula komitmen karier karyawan tersebut. 


\section{DISKUSI}

Pada penelitian ini, ditemukan 10 artikel yang relevan untuk dikaji terkait faktor-faktor yang mempengaruhi komitmen karier. Dari 10 artikel publikasi tersebut, 5 artikel melibatkan pekerja atau karyawan sebagai subjek penelitian, 3 artikel melibatkan guru, 1 artikel melibatkan mahasiswa, dan 1 artikel melibatkan ahli kimia/ laboran. Hal tersebut menunjukkan bahwa komitmen karier tidak hanya ditemukan pada lingkup kerja seperti karyawan, guru, dan laboran tetapi juga dapat ditemukan pada mahasiswa. Penelitian pada subjek selain pekerja masih jarang (misalnya pada mahasiswa) dapat disebabkan oleh pengalaman kerja yang sedikit jika dibandingkan dengan subjek yang telah bekerja karena pengalaman kerja memiliki pengaruh pada komitmen karier individu (Arnold, 1990; Nazish, dkk., 2013). Selain itu, mayoritas dari 10 artikel publikasi tersebut menggunakan alat ukur komitmen karier milik Blau (1985). Hal tersebut dapat dikarenakan Blau (1985) merupakan tokoh pertama yang menyusun alat ukur yang valid dan reliabel untuk digunakan dalam mengukur komitmen karier.

Berdasarkan kajian pada 10 artikel publikasi diketahui bahwa komitmen karier dipengaruhi oleh berbagai faktor, antara lain: komitmen organisasi, keterlibatan kerja, kepuasan kerja, nilai kerja, situasi kerja, pengalaman kerja, kepribadian, dan self-efficacy. Pada penelitian ini, peneliti memasukkan variabel-variabel tersebut dalam 2 kategori yaitu faktor internal dan eksternal. Faktor internal adalah faktor-faktor yang muncul dari dalam diri individu sedangkan faktor eksternal adalah faktor yang muncul dari luar diri individu. Faktor internal yang mempengaruhi komitmen karier, yaitu: komitmen organisasi (Goulet \& Singh, 2002; Nazish, dkk., 2013), keterlibatan kerja (Goulet \& Singh, 2002), kepuasan kerja (Goulet \& Singh, 2002; Nazish, dkk., 2013), nilai kerja (Ching \& Kee, 2012), pengalaman kerja (Nazish, dkk., 2013), kepribadian (Arora \& Rangnekar, 2016; Xiao, dkk., 2014), dan self-efficacy (Niu, 2010). Adapun, faktor eksternal yang mempengaruhi komitmen karier, yaitu situasi kerja (Nazish, dkk., 2013; Smith, Conley, \& You, 2015; Ugboro \& Obeng; 2015; Cai, 2017; Pasha, Hamid, \& Shahzad, 2017) yang meliputi kondisi kerja, persepsi pensiun, persepsi terhadap ancaman dalam bekerja, dorongan yang ditawarkan organisasi (offered inducements), kontribusi yang diharapkan organisasi (expected contributions), peluang promosi, dan reward.

Namun, penelitian yang dilakukan Animasahun dan Oludemi (2013) menunjukkan hasil yang berbeda di mana tidak ditemukan adanya dampak yang signifikan dari kepuasan kerja dan pengalaman kerja terhadap komitmen karier. Hal tersebut dapat terjadi karena kriteria subjek dan lingkungan tempat tinggal subjek yang berbeda.

Keterbatasan dalam penelitian ini adalah kesulitan untuk mengakses artikel publikasi secara full-text (lengkap). Mayoritas dari artikel penelitian yang dipublikasikan secara online, hanya menyajikan abstrak dari penelitiannya saja. Selain itu, masih jarang ditemukan penelitian tentang komitmen karier di Indonesia sehingga peneliti memilih untuk menggunakan artikel publikasi dalam internasional (berbahasa Inggris). 


\section{SIMPULAN DAN IMPLIKASI}

Hasil studi menunjukkan bahwa komitmen karier tidak hanya dipengaruhi oleh faktor dari dalam diri individu saja (internal), tetapi juga dapat dipengaruhi oleh faktor dari luar (eksternal). Faktor internal terdiri dari komitmen organisasi, keterlibatan kerja, kepuasan kerja, nilai kerja, pengalaman kerja, kepribadian, dan self-efficacy sedangkan faktor eksternal terdiri dari situasi kerja yang meliputi kondisi kerja, persepsi pensiun, persepsi terhadap ancaman dalam bekerja, dorongan yang ditawarkan organisasi (offered inducements), kontribusi yang diharapkan organisasi (expected contributions), peluang promosi, dan reward.

Peneliti belum menemukan penelitian yang membahas mengenai intervensi yang dapat meningkatkan komitmen karier baik dalam setting individu, kelompok atau komunitas. Disarankan pada peneliti selanjutnya untuk mengembangkan penelitian terkait intervensi pada komitmen karier. Selain itu, peneliti selanjutnya dapat menggunakan subjek lain di luar karyawan dan mengembangkan alat ukur terbaru untuk mengukur komitmen karier.

\section{REFERENSI}

Alzyoud, A.A.Y. (2017). The predictors of career success. International review of management and marketing, 7, (2), 22-26.

Animasahun, R.A. \& Oludemi, O.M. (2013). Demographical and psychological factors as correlates of organisational and career commitment among prison officers in Southwest, Nigeria. Journal of Emerging Trends in Educational Research and Policy Studies (JETERAPS), 4, (6), 878-887.

Arora, R. \& Rangnekar, S. (2016). The interactive effects of conscientiousness and agreeableness on career commitment. Journal of Employment Counseling, 53.

Ballout, H.I. (2009). Career commitment and career success: moderating role of selfefficacy. Career Development International, 14, (7), 655-670.

Blau, G. (1985). The measurement and prediction of career commitment. Journal of Occupational Psychology, 58, 277-288.

Cai, H., dkk. (2017). Career Commitment in STEM A Moderated mediation model of inducements, expected contributions, and organizational commitment. Journal of Career Assessment, 1-18.

Ching, S.L. \& Kee, D.M.H. (2012). Work values-career commitment relationship of generation Y Teachers in Malaysia. IPEDR, 28.

Collarelli, S. M., \& Bishop, R. C. (1990). Career commitment: Functions, correlates, and management. Group and Organization Studies, 15, 158-176.

Ellemers, N., de Gilder, D.., \& van den Heuvel, H. (1998). Career-oriented versus teamoriented commitment and behavior at work. Journal of Applied Psychology, 83(5), 717-730. 
Goulet, L.R. \& Singh, P. (2002). Career commitment: A reexamination and an extension. Journal of Vocational Behavior, 61, 73-91.

Hall, D. T. (1971). A theoretical model of career subidentity development in organizational settings. Organizational Behavior and Human Performance, 6, 5076.

Hellriegel, D., \& Slocum, J. W. (2011). Organizational behavior 13th Edition. USA: Cengage Learning.

Ismail, A., Madrah, H., \& Abdin, F. (2014). The influence of career commitment on organizational commitment among selected bankers in Lagos Metropolis, Nigeria. International Journal of Contemporary Business Management, 1, 1, 30-40.

Nazish, A., Amjad, R., Mehboob, S.A.A., Rizwan M., \& Sajid. (2013). Job \& career influences on career commitment among rmployees of Banking Sector the mediating effect of job satisfaction \& organizational commitment. International Journal of Business and Management Invention, 2, (11), 47-54.

Niu, H.J. (2010). Investigating the effects of self-efficacy on foodservice industry employees' career commitment. International Journal of Hospitality Management, 29, 743-750.

Pasha, A.T., Hamid, K.A., \& Shahzad, A. (2017). Mediating role of career commitment in the relationship of promotional opportunities, rewards and career success. Pakistan Journal of Statistics and Operation Research, 13(1), 185-199.

Siswanto. (2010). Systematic Review sebagai Metode Penelitian untuk Mensintesis Hasil-Hasil Penelitian (Sebuah Pengantar). Pusat Penelitian dan Pengembangan Sistem dan Kebijakan Kesehatan, Badan Litbang Kesehatan, Kementerian Kesehatan.

Smith, J.L., Conley, S., \& You, S. (2015). Perceptions of retirement affect career commitment: The mediating role of retirement system satisfaction for two teacher age groups. Educational Gerontology, 41, 267-281.

Ugboro, I.O. \& Obeng, K. (2015). The moderating effects of perceived threat to valued job features on career commitment among university professors. Australian Journal of Career Development, 24(1), 39-52.

Xiao, W., Zhou, L., Wu, Q., Zhang, Y., Miao, D., Zhang, J., \& Peng, J. (2014). Effects of person-vocation fit and core self-evaluation on career commitment of medical university students the mediator roles of anxiety and career satisfaction. International Journal of Mental Health Systems. 